\title{
How Entrepreneurial Legends, Heroes and Meccas are Born
}

\author{
Howard E. Aldrich (University of North Carolina at Chapel Hill) \\ Stephen Lippmann
}

KEYWORDS: Entrepreneurship, Innovation, Organization, Information Technology, Leadership, Startups.

Entrepreneurship history is filled with events, places and people who are now legendary or even sacred. In the beginning of the 20th century, New York's Lower East Side became a place where Jewish immigrants could hatch new businesses, building their own fortunes and those of successive generations. In the 1930s, Stanford University students Dave Packard and Bill Hewlett built an audio oscillator in their garage, launching a company and the fortunes of the Silicon Valley (In time that garage would become a museum and the equivalent of the Sistine Chapel for technology entrepreneurs). In the 1950s and 60s, the "Traitorous Eight" engineers who joined Robert Noyce in founding Fairchild Semiconductor started a new, collaborative way for technical people to work together, establishing a new model for future Silicon Valley entrepreneurs to run their own companies.

In these cases and others, at some point the people involved realized they were part of something bigger than themselves, that they were transforming an industry and a place, and that what they accomplished would influence future generations of entrepreneurs. In our paper entitled "Generational Units, Collective Memory and Entrepreneurship," we deconstruct how this process happens and provide a new way of looking at how entrepreneurial legends, heroes and meccas are born. While serendipity played a part - having the right people in the right place at the right time in history - the key players (whom we call "generational units") also took deliberate actions to preserve their legacies and establish a framework for future companies and generations of entrepreneurs. Their actions and experiences are worth examining for those who study and teach entrepreneurship, and for policymakers who hope to influence the design of new places where entrepreneurs and their companies can thrive.

Here is an abridged version of our paper. See A Rolling Stone Gathers Momentum

(https://journals.aom.org/doi/10.5465/amr.2014.0139) for the longer version.

\section{Generational Units, Collective Memory, and Entrepreneurship}

Entrepreneurs and their innovations have often changed the course of history, but historical conditions also shape the trajectory of entrepreneurship (Schumpeter, 2003). This article considers how "generational units" which are meaningful social collectives - and "collective memories" - which are the shared accounts of the past - can shape entrepreneurial action. By creating collective memories, entrepreneurs can leave imprints that persist and influence future entrepreneurial activity (Lippmann and Aldrich 2016).

\section{Entrepreneurial Generational Units}

Our concept of "generational units of entrepreneurs" was inspired by Mannheim (1952), who proposed another way to describe "generations" beyond merely groups of people born at roughly the same time. Mannheim suggested the term "generational unit," defined as a concrete group defined by a shared social location (not necessarily physically proximate to one another) who not only share the same historical experiences at roughly the same age but also have a shared understanding of those experiences. These individuals coalesce into a self-conscious group based on date of birth, social proximity to historical events, and an awareness of the ways in which those events connect them to others in that group. Members of a generational unit believe that they share at least part of their identity with others; and they actively work in concert to shape their group, public perceptions of it and the ways it persists (Joshi, Dencker, Franz, \& Martocchio, 2010).

In our research, we uncovered many examples of entrepreneurs who shared similar social locations and 
moved through similar experiences in a region at the same time, as we will point out. They were connected not only by their shared experiences but also but a common understanding of what those experiences meant for the region's economy. Although they often were similar in age, more important was their shared interpretation of their experiences.

We therefore define entrepreneurial generational units as groups of entrepreneurs who emerge within meaningful local or regional spaces and are reflexive and self-aware. This concept focuses our attention on the ways in which historical contexts imprint social groups in a specific location and time, and continue to influence them over time. By shaping memories of themselves, their formation and their histories, generational units of entrepreneurs imprint themselves in the collective memory and provide a framework that shapes future entrepreneurial action.

\section{The Development of Entrepreneurial Generational Units: Catalysts + Triggering Events that Result in the Emergence of Generational Units}

In this section, we argue that generational units of entrepreneurs emerge through an interaction among important catalysts - including pioneering individuals and points of common reference that we label "boundary objects" - alongside important triggering events in the social landscape.

\section{Pioneers}

Under certain conditions, pioneering entrepreneurs (whom we define to be entrepreneurs who are the earliest founders of new kinds of businesses in an area) can exert substantial influence over the course of events in a region. For instance, the famous "Traitorous Eight" engineers who joined Robert Noyce in founding Fairchild Semiconductor in the 1950s and 1960s made use of cooperation, transparency and openness to foster a high rate of innovation in the region. They also created the more consensually oriented organizational forms that continue to dominate Silicon Valley to this day. Another example from Silicon Valley was the flow of spinouts from Xerox Parc in the 1970s and 1980s. Hiltzik (1999) chronicled the stories of scientists, engineers, administrators and executives who developed much of the technology of personal computers and the internet. Through shared experiences at Xerox Parc and then in their separate organizations, they constituted a new generational unit in Silicon Valley that expanded the frontiers of high technology.

\section{Boundary Objects}

The actions of pioneering entrepreneurs can result in a coalescence around shared symbols, objects and ideas, such as a successful local firm that becomes legendary, a buzz word that captures the "feel" of a location, and a charismatic leader who champions local causes (Star \& Griesemer, 1989). It doesn't matter if what entrepreneurs "believe" about their area is literally true. What matters is that the people involved perceive that it is true and so taken for granted that they spend little or no time discussing its veracity. Consider the term "startup scene," which functions like a boundary object in this context: it can reference a physical place, a collection of individuals, and an aspirational claim to be taken seriously by journalists who report on technological innovation. Boundary objects stimulate members of generational units to perceive that they share a strong basis of collective identity and collaborative action (Phillips, Lawrence, \& Hardy, 2004). That perception becomes strong enough to motivate collective action.

\section{Triggering Events}

Social and historical events generate new roles for social actors in a region. To the extent that people take on new roles that involve business development, startups, fund-raising and other activities that involve them in entrepreneurial activities, such roles contribute to the growth of entrepreneurial units. People begin meeting one another in contexts where they must consider the well-being of the entire region, rather than just their own small piece of it. The disruptive nature of triggering events creates periods of susceptibility, during which entrepreneurs and industries are highly sensitive to external influences (Marquis \& Tilcsik, 2013). We focus on two that are particularly salient for the emergence of entrepreneurial generational units: migration and nascency.

Migration: Migration can create periods of susceptibility during which groups of entrepreneurs are likely to emerge as generational units. Immigrant entrepreneurs often form cohesive communities in their destination cities (Sepulveda, Syrett, \& Lyon, 2011). For example, Jewish immigrants to New York around the turn of the twentieth century were concentrated on the Lower East Side, often working in the same narrow range of occupations and industries. These immigrants 
trusted and supported one another. They created financial institutions that lent capital to one another and social organizations that helped them interact informally. The resulting social capital - growing networks of trusted others who held the perception that they shared a common fate -- partially explains the high rates of entrepreneurship among Jewish immigrants to New York around that time (Godley, 2001).

Nascency: Groups of entrepreneurs who are among the first entrants into a new industry are also more likely to form an entrepreneurial generational unit. As entrepreneurs establish the "rules of the game" in an emerging industry, they often enact a collective identity that shapes further development (Hjorth \& Johannisson, 2003). In Silicon Valley, semiconductor firms, local bars and restaurants, and the Valley itself all served as important focal points that united these early technology entrepreneurs into a cohesive group: many of these entrepreneurs spoke of being a "part of something" which was in large part the coalescence of a generational unit of entrepreneurs that continued to exert an influence in the following decades (Berlin, 2005; Malone, 2002). Over the ensuring decades, the feeling of shared fate extended into community voluntary and non-profit associations, such as the Mountain View Los Altos Soccer Club for the children of the region's tech entrepreneurs and the Bay Area Glass Institute (BAGI), formed in 1996 to educate people in the region by hosting glass art exhibits, teaching classes and operating a glass studio.

\section{Launching the Legend}

Generational units can arise at any place and at any time and be shaped by forces beyond their control. But why some become embedded in the collective consciousness and persist over time depends on the degree to which generational units can imprint their actions and ideas on the collective memory -- a more deliberate process. Generational units use four mechanisms to create memories, help these memories persist over time and promote conditions ideal for entrepreneurial activity: philanthropy, mentorship, institution building and technologies of memory.

\section{Public Philanthropy}

After leaving their firms, many pioneering entrepreneurs with positive reputations and local influence continue to work in leadership roles and build legacies through philanthropy. In many cases, this happens through the sponsorship of university centers for entrepreneurship
(Katz, 2003; Ewing Marion Kauffman Foundation, 2008). By taking on highly visible roles in funding activities devoted to advancing public welfare, pioneers gain a powerful platform from which to imprint their shared understanding of a region's history. By recruiting others to leadership roles in their philanthropic ventures, pioneers shape the narrative that will be passed along and thus imprinted on younger generations.

\section{Mentorship}

Prominent entrepreneurs on the leading edge of industry may also give time and provide mentorship to new entrepreneurs (Ozgen \& Baron, 2007). For instance, because of his position of prominence in the generational unit of first-generation Silicon Valley entrepreneurs, Robert Noyce was positioned to mentor many figures from the next wave of technology start-ups that relied on the integrated circuit he helped create. Mentoring results in imprinting through pioneers fostering a shared vocabulary of motives among a region's emerging entrepreneurs, defining and interpreting past actions in terms of "what's good for the region."

\section{Institution Building}

Cohesive generational units of entrepreneurs are particularly effective agents for creating the institutions that sustain a region's entrepreneurial activity. The second wave of entrepreneurship in Silicon Valley reinforced the networks, venture capitalists, vendors, law and public relations firms, and customers that had emerged through the first wave of the industry's emergence (Berlin, 2005: 253-254). Rather than developing their own interpretations of a region's history, participants in the "second wave" were primed to accept the narrative promulgated by the pioneers who established the institutions. Institutions such as the Tech Museum of Innovation in San Jose provide a physical manifestation of the region's successful development.

\section{Technologies of Memory}

Generational units are strengthened by "technologies of memory," which are devices that capture and carry memories in a collective sense (Olick, 1999). Memories may be symbolized or embodied in a physical object or a specific place. Such stories about entrepreneurial action (no matter how apocryphal) can create powerful collective memories. For example, the legendary stature of Silicon Valley's entrepreneurial history persists in the continued fascination with places like the "HP garage," 
which help to sustain a belief in the lure of the area and the serendipity of entrepreneurial success there (Audia \& Rider, 2005).

\section{Continuing the Legacy Cements a Region's Advantage}

Once generational units of entrepreneurs insinuate themselves and their legacies into the collective identities of particular regions, how do they persist? In addition to embedding these identities in the institutional and historical structures of areas, the identities they create become part of the collective memory and shape not only common beliefs that tap into that shared memory, but also entrepreneurial ambition and migration patterns for future generations. A stock of boundary objects facilitates the formation of identities drawing on collective memories, such as stereotypes of a region being hospitable to certain "types" of migrants (Molotch, Freudenberg and Paulsen 2000).

"Types" of migrants can refer to such things as ethnicity, moral character, or lifestyle preferences, as noted by Kaufman and Kaliner (2011). They hypothesized that stereotypes of places, which exist in the collective memory over time, draw people through a process of "idio-cultural migration." Current stereotypes about a place draw sympathetic migrants, who then contribute to the ongoing stereotyping of a region. In their case study of New Hampshire and Vermont, they found that through an active strategy of branding and tourism promotion, Vermont transitioned from one of the most conservative states in the union into a beacon for left-leaning Americans, whereas New Hampshire, which avoided such a promotional plan, remains deeply conservative. Once Vermont was branded as a skiing and outdoor mecca, and drew vacationers and affluent temporary residents interested in those lifestyles, it emerged in the collective consciousness as a place "for" those kinds of people. As a result, new migrants interested in a lifestyle characterized by liberal political ideologies and laid-back lifestyles were drawn there permanently, cementing the state's idio-culture.

A similar and very powerful chain appears to exist in entrepreneurial regions. Legendarily innovative regions tend to draw educated and innovative people. They may be attracted because traditional, firm-based jobs await them there, but they also may be drawn because the regions contain the "scenes" hopeful entrepreneurs wish to be a part of (Moretti 2012; Castells 2014).
Indeed, some have argued that spinoff activities contribute significantly to sustained regional economic advantage (Boschma 2015). At the firm level, technology companies hoping to boost innovation and competitiveness often open branches in Silicon Valley in hopes of capturing some of the "magic" of the region. These branches themselves have been responsible for spawning a significant number of spinoffs and entrepreneurial endeavors (Adams 2011). Regions widely known for their entrepreneurial activity attract others hoping to replicate the famous success stories that live on in the collective memory.

The Research Triangle Park in North Carolina, although established in 1951, only a few years after Silicon Valley began its ascent, struggled to create its own unique history because it could not disentangle itself from the histories of the three local universities and the international identities of the major firms locating there, e.g. IBM and Northern Telecom. Only when several waves of downsizing hit the region, due to corporate mergers and consolidations, did a separate entrepreneurial identity begin to emerge via the many small firms created by ex-corporate employees.

\section{A New Focus for Teachers and Scholars}

In applying generational concepts to entrepreneurship, we have emphasized two factors. First, we noted how "triggering events" like migration and new industries help individuals form generational units with shared experiences, self-awareness, and meaning-making. During periods of disruption and transformation, people are particularly susceptible to the influence of strong social and emotional forces in their environments. In such periods, generational units in regions may be imprinted with an entrepreneurial orientation that marks them off from previous generations. Second, we outlined the ways in which generational units persist and create durable memories that persist for decades by exercising leadership, creating legacies, building supportive institutions and enacting technologies of memory. Our argument stressed that the persistence of generational units is not automatic, but rather depends upon collaborative and collective action by the people within them.

Among organization and management scholars, recognition is growing that history matters for organizational theory (Lippmann and Aldrich 2014; 
Rowlinson, Hassard and Decker 2014), and generational concepts provide a fruitful avenue for incorporating history into entrepreneurship studies in a meaningful, multilevel way. Despite the growing attention paid to the importance of generations in the social sciences and to generational differences in work orientations and entrepreneurship by the popular media, only a few have looked closely at generational differences as applied to entrepreneurship studies. In response, we have outlined an approach to studying entrepreneurship that identifies ways in which generational concepts may enrich our understanding of entrepreneurial dynamics. We moved beyond purely demographic definitions of generations and instead focused on the social and historical dynamics that lead to meaningful collectives, with high degrees of selfawareness and a shared entrepreneurial identity. We argue that these concepts, frameworks and ideas offer historically informed insights into our understandings of entrepreneurial dynamics.

We have argued that generational units are important mechanisms involved in the processes of social evolution and social change. As groups and societies reproduce themselves from generation to generation, those members that comprise new generations (or generational units) are predisposed to view the world through an historically conditioned lens. Because "members of any one generation can participate only in a temporally limited section of the historical process" (Mannheim 1952:292), a new generation comes into "fresh contact" with existing social, economic and historical circumstances. This de novo contact allows for new interpretations of those circumstances in a way that is somewhat disconnected from those of previous generations, who had different experiences with them and thus hold different understandings. These diverse interpretations often lead to dissimilar responses to the same events. When collectives of entrepreneurs make meaning out of their actions and embed those meanings in the collective memory, they shape the trajectory of future entrepreneurial activities.

\section{Creating the Conditions for New Generations}

The generational memories that provide coherence to generational units provide a useful theoretical mechanism for linking historical, social and cultural contexts to individual actions and agency. Generational units and the collective memories they sustain over time reconnect agency and structure in the study of entrepreneurship by regarding individuals as the conduits through which social structures persist and shape future entrepreneurial action (Haveman, Habinek and Goodman 2012; Van de Ven and Lifschitz 2013). From a macro-structural perspective, we have argued that regional infrastructure and social networks matter for the development of generational units. We have shown how critical periods in development matter for the emergence of generational memories, and posited a number of important factors that might be directly relevant to the emergence of entrepreneurial generational units. By providing a mnemonic link between individual-level action to not only the social context in which those actions occur, but also to the historical processes that shaped them, generational units and generational memories can shed new light on the ways in which history matters for entrepreneurship studies and for policy makers hoping to foster economic growth through entrepreneurship. For example, regions hoping to attract young entrepreneurs must establish an infrastructure in which those entrepreneurs can cohere into a meaningful social unit so that information, knowledge and an entrepreneurial identity is more easily distributed and accessible.

Entrepreneurs are agents of social and economic change, but they carry out their actions in particular institutional contexts. The integration of those individual actions and the ways in which they are influenced by contextual factors is a major thrust of entrepreneurship research, although much of the literature tends to favor one at the expense of the other (Aldrich 2011). We have proposed a focus on the historiographical concepts that emerge from generational theory as a fruitful way to integrate structure and agency. In our view, entrepreneurs are the carriers of history, as generational memories shape their actions, but also have the power to transform the status quo, as the new organizations and new models for organizing differ from those created under different historical circumstances. Incorporating generational concepts into research on entrepreneurship will help to more fully incorporate history into our understanding of entrepreneurial and organizational processes.

\section{References}

Adams, S. B. (2011). "Growing where you are planted: Exogenous firms and the seeding of Silicon Valley." Research Policy 40(3): 368-379. 
Aldrich, H. E. (2011). "Heroes, Villains, and Fools: Institutional Entrepreneurship, NOT Institutional Entrepreneurs." Entrepreneurship Research Journal 1 (2): 1-3.

Boschma, R. (2015). "Do Spinoff Dynamics or Agglomeration Externalities Drive Industry Clustering? A Reappraisal of Steven Klepper's Work." Industrial and Corporate Change 24(4): 859-873.

Castells, M. (2014). Technopoles of the World: The Making of $21 \mathrm{st}$ Century Industrial Complexes, Routledge.

Haveman, H. A., J. Habinek and L. A. Goodman (2012). "How Entrepreneurship Evolves: The Founders of New Magazines in America, 1741-1860." Administrative Science Quarterly 57(4): 585-624.

Hiltzik, M. A. (1999). Dealers of lightning : Xerox PARC and the dawn of the computer age. New York, HarperBusiness.

Kaufman, J. and M. E. Kaliner (2011). "The Reaccomplishment of Place in Twentieth Century Vermont and New Hampshire: History Repeats Itself, Until it Doesn't." Theory and Society 40(2): 119-154.

Lippmann, S. and H. E. Aldrich (2014). History and Evolutionary Theory. Organizations in Time: History, Theory, Methods. Lippmann, S. and H. E. Aldrich, Eds. New York, Oxford University Press: Forthcoming.

Lippmann, S. and H. E. Aldrich (2016). "A Rolling Stone Gathers Momentum: Generational Units, Collective Memory, and Entrepreneurship." Academy of Management Review 41(4): 658-675.

Mannheim, K. (1952). The Problem of Generations. Essays on the Sociology of Knowledge by Karl Mannheim. Mannheim, K., Ed. New York, Routledge and Kegan Paul: 276 - 321.

Molotch, H., W. Freudenberg and K. E. Paulsen (2000). "History Repeats Itself, but How? City Character, Urban Tradition, and the Accomplishment of Place." American Sociological Review 65(6): 791-823.

Moretti, E. (2012). The New Geography of Jobs. New York, Houghton Mifflin Harcourt.

Rowlinson, M., J. Hassard and S. Decker (2014).
"Strategies for Organizational History: A Dialogue between Historical Theory and Organizaton Theory." Academy of Management Review 39(3): 250-274.

Van de Ven, A. H. and A. Lifschitz (2013). "Rational and Reasonable Microfoundations of Markets and Institutions." The Academy of Management Perspectives 27(2): 156-172.

\section{Further Reading}

How Cities and Regions Can Become Thriving Entrepreneurial Hubs (https://eiexchange.com/content/77-how-cities-and-regi ons-can-become-thrivingentre?search=How\%20Cities\%20and\%20Regions) , EIX.com, March 2015 